\title{
AirQ Sonification as a context for mutual contribution between Science and Music
}

Julián Jaramillo Arango (Caldas University Manizales, Colombia)

julianjaus@yahoo.com

\begin{abstract}
This paper addresses a high-level discussion about the links between Science and Music, focusing on my own sonification and auditory display practices around air quality. Grounded on recent insights on interdisciplinarity and sonification practices, the first sections will point out some potential contributions from scientific research to music studies and vice versa. I will propose the concept of mutualism to depict the interdependent status of Music and Science. The final sections will discuss air contamination as a complex contemporary problem, and will report three practice-based-design projects, AirQ jacket, Esmog Data and Breathe!, which outline different directions in facing local environmental awareness.

Keywords. Science and Music, Sonification, Environmental Awarness, Sonology.
\end{abstract}

A sonificação do AirQ como um contexto de contribuição mutua entre a Ciência e a Música.

Resumo. Este artigo levanta uma discussão geral sobre as relações entre a Ciência e a Música, e se concentra em minhas praticas de sonificação e display auditivo da qualidade do ar. Baseado em reflexões recentes sobre a interdisciplinaridade e as práticas de sonificação as primeiras seções identificam algumas contribuições potenciais da pesquisa científica aos estudos musicais e vice versa. O conceito de mutualismo será proposto para expressar a interdependência entre Música e Ciência. As seções finais discutem a contaminação do ar como um problema complexo de nossos dias e descreve três projetos de design-baseado-na-prática, AirQ jacket, Esmog Data e Breathe! que propõem direções diferentes para gerar consciência ambiental no contexto local.

Palavras chave. Ciência e Música, Sonificação, Consciência Ambiental, Sonologia.

\section{Introduction}

Since the ancient world the concept of nature has linked Science and Music. However, in the $20^{\text {th }}$ century modern physics and mathematics have promoted a shift of mind about the understanding of the surrounding reality and it has impacted music making. One example of this is composer Iannis Xenakis, whose notion of nature is not dependent on mimesis:

But it is important to note that the kind of nature he is referring to is the one supplied by modern science. It is far removed from, say, the naturalistic views proper to Classicism or Taoism - Nature as Harmony. This is fundamental to understand Xenakis' "naturalism". The nature he is referring to is the one of thermodynamics, of probabilities, of Brownian movements, etc. It was then normal that he expresses an interest in chaos theories, which were popularized only in the end of the 1970s and on. (SOLOMOS, 2005)

By grounding his music on modern physics and mathematical theories, Xenakis has contributed to the popularization of a shared basis about the answers that science provides to society.

This paper addresses a high-level discussion about the mutual relations between Science and Music, focusing on my own sonification and Auditory Display (AD) practices around air quality. I will discuss aspects of sonification and AD that can extend the scope of both, scientific research and musical studies. The paper is organized in four sections. In the first one, I will comment and compare arguments from two recent papers providing criteria to understand the logics of interdisciplinarity between Art and Science and the diverse directions that sonification projects can follow. In the second section, I will summarize the contributions from both ways. The third section is concerned with scientific and social aspects of air contamination, since it was an inspiring topic in the creation of three sonifi- 
cation projects: AirQ jacket, Esmog Data, and Breathe!. While reporting some of the project based research findings in the final section, I will discuss separately sonification and auditory display strategies adopted in the three projects.

The projects propose three different directions in facing local environmental awareness. They were created along with the Caldas University Design and Creation program in Manizales, Colombia, under a two-year postdoctoral research entitled Sound Design for the Urban Space.

\section{Mutualism between Music and Science}

Sonification and Auditory Display practices are usually taken as examples of the interdisciplinarity between Music and Science. In her analysis of sonification projects dealing with natural phenomena, Alexandra Supper suggests "legitimacy exchange" to point out the rhetorical support that a scientific field can provide to another (SUPPER, 2014). By analyzing the motivations of particular projects, Supper raises arguments about the positive role of art in particular scientific endeavors. Moreover, she discusses the rationale of music creation and reception in artistic sonification.

Supper`s arguments take into consideration the study about the public understanding of art-science by Georgina Born and Andrew Barry, which reports an ethnographic research of art-science practitioners and institutions in the USA, UK and Australia. The authors claim a neglected diversity of the field; hence they propose accountability, innovation and ontology as three different logics of the interdisciplinarity between Art and Science. The contextualization of the findings achieved inside the laboratory is an unavoidable stage in scientific endeavors dependent on public funding. By accountability Born \& Barry “... refer to a series of ways in which scientific research is increasingly required to make itself accountable to society" (BORN \& BARRY, 2010). Moreover, making scientific research more accessible to the public contributes to the growth of modern knowledge economies. It relates to the logic of innovation, which draws “... attention to a range of arguments about the need for scientific research to fuel industrial or commercial innovation and economic growth" " (BORN \& BARRY, 2010). In the case of Sonification and AD, the logics of accountability and innovation suggest a biased partnership between Music and Science. As a recipient for the popularization of scientific knowledge, Music enriches research endeavors with alternative strategies to target the public sphere. Conversely, the contributions provided by Science to the field of Music will be found in the logic of ontology: "an orientation in interdisciplinary practices towards effecting ontological change in both the object(s) of research, and the relations between research subjects and objects".

By extending the authors reflection, the biological metaphor of mutualism depicts the interdependent status of Music and Science in sonification practices. Although this concept is mainly concerned with living beings, mutualism refers to a particular relationship between Science and Music in which each field benefits from the activity of the other. In this regard, I will now summarize contributions from both, Science and Music. In other words, I will discuss in which aspects sonification and AD are extending the scope of both, scientific research and musical studies.

\section{Summarizing mutual contributions}

The topics I will discuss derive from two sources. The first one is the Supper`s analysis of scientific and artistic sonification projects. While it comes from a Science \& Technology scholar, it seems a reasonable task counterbalancing some of these views from a 
musical composer perspective. The other source is my own sonification and AD research around air quality, which has advanced in a series of three creative projects. They will be described in the third section of this paper.

\subsection{From Music to Science}

Supper argues that the most valuable contribution of sonification is spreading scientific knowledge to the public. With this claim, she challenges the mainstream research in sonification and AD, which focus on sound as a scientific tool by taking advantage of sound 's non-visual, time-depending and symbolic capabilities as a conveyor of data. While some sonification experiments are used on applications such as alarms, alerts, warnings, monitoring or status and process indicators, others relies on data exploration and "... use sound to offer a more holistic portrait of the data" (WALKER \& NESS, 2010).

Allied to the logic of innovation, scientific sonification projects provide alternative (to visual and verbal) approaches to explore known data. Furthermore, under unpredictable, chaotic situations or those involving large amount of data, sonification is also explored in the recognition of patterns and new meanings. It is worth mentioning that in scientific sonification, musical content emerges as an involuntary product. Since low-level musical units such as notes, chords, melodies or even audio samples are regular material in the data-to-sound mapping processes (BERGER \& GROND) complex musical structures inevitably raise as a residue

Although Supper`s assumption is not shared by the sonification and AD academic community, it does let see sonification contributions under the logic of scientific accountability. Artistic and musical experiments with sonification contribute to the public spreading and understanding of scientific knowledge. If a scientist finding that was achieved inside the laboratory should take effect outside his peers' context, knowledge accessibility should be taken into account from the research conception. Moreover, providing social meaning to scientific knowledge strengthens a shared basis about the answers and solutions that science provides to society.

\subsection{From Science to Music}

The musical need of a data domain from which content could be generated arouse when the second Viennese school disrupted the course of academic musical composition by deliberately rejecting the tonality and adopting twelve-tone techniques. While a generation of subsequent composers devoted to the integral or total serialism extended the ways in which the data domain was applied to music by mapping the series to diverse musical parameters, other composers explored modern mathematical models as data domains (McLAUGHLIN, 2016). In this musical tradition, the case of composer Iannis Xenakis (1922-2001) remains as a remarkable example of shared aims between sonification and $20^{\text {th }}$-century musical composition. When discussing the Xenakis` interest for cellular automata, Makis Solomos raises concepts such as "fluid turbulence" and "automation" (SOLOMOS, 2005) as natural forces whose internal dynamics and emerging behavior gave rise to his orchestral work Horos (1986). Artistic works such as the Storm Sonification Project (POLLI, 2005) or the Sonic Pavilion (ATKINS, 2009) suggest a resumption of Xenakis` interest for the internal structure of nature as a data-domain. According to Supper, by allowing the spectator to witness phenomena that can otherwise only be perceived in the wild, at one's own peril, such as meteorological or telluric activity, artistic sonification can lead the listener to a overwhelming, sublime experience (SUPPER, 2014). From an aesthetic perspective, the 
goal of sonification would be producing “...auditory representations that give insight into the data or realities they represent to enable inference and meaning making to take place" (BARRAS \& VICKERS, 2011). Sonification explores ways of listening not usually related to music, since it relies on the fourth Schaefferian mode or function, Comprendre, which comprises “...symbolic (i.e. consensual) relations between representamen and object” (PALOMBINI, 1999) and is activated when facing a "... structure that has a sense and meaning for those listeners who share the code" (SMALLEY, 1996). By triggering supplementary meanings to sound and creating auditory images of reality, sonification suggests an ontological transformation and novel interpretations of the encrypted data.

The displacement of the composer, listener and performer role was one of the John Cage insights giving rise to sound art (CHARLES, 2010). By adopting chance operations as the data domain, Cage was deliberately renouncing to his intentions as a composer, letting the world speak at its own pace and accepting its indeterminate content without creating expectations. This philosophical principle of $20^{\text {th }}$ century music theory, composition and sound art is identified by Supper in Sonification projects as a "self-denying tendency on the part of many composers who are compelled by the possibility of removing the individual from the act of composition" (SUPPER, 2014). While the data domain provides the content, letting the composer to put aside his intentions and expectations, the compositional decisions are then displaced to play an indirect role in the process. In sonification and AD practices, the composer do have different creative tasks, most of them related to the representation of data, the mapping of the non-sounding information, the raising of auditory images of reality or the construction of listening environments relevant to the sonified data. In many cases, artistic sonification endeavors are sound art installations, design projects, objects or systems rather than pieces of music.

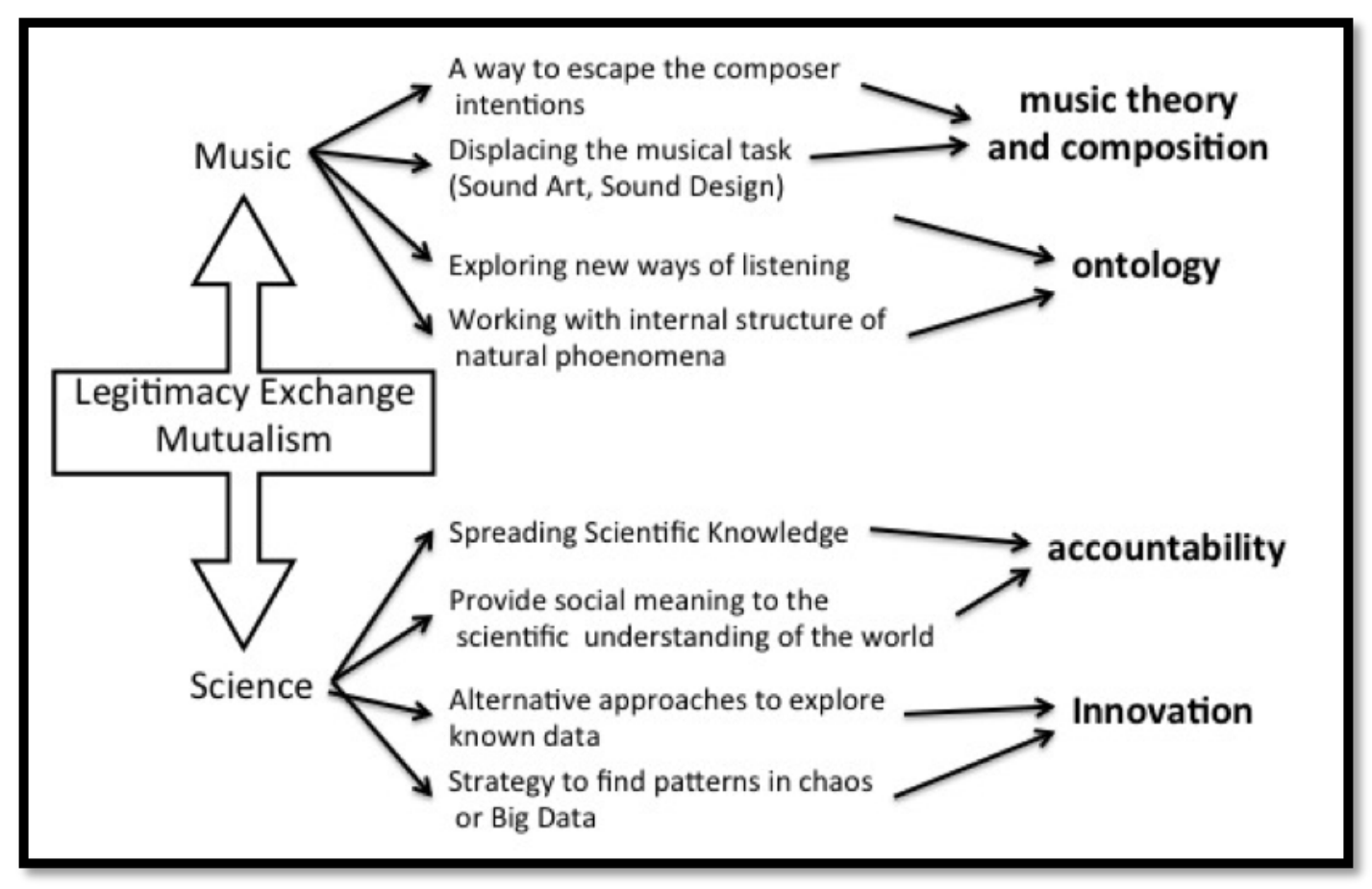

Figure 1: Summary of mutual contributions between Science and Music

\section{The AirQ problem}

With regard to climate change, the World Health Organization has warned about "the increasing temperatures, sea-level rises, changing patterns of precipitation, and more 
frequent and severe extreme events.” These phenomena “...are expected to have largely adverse effects on key determinants of human health, including clean air and water, sufficient food and adequate shelter" (WHO, 2016). Monitoring air quality has become an important demand for any city council since pollution affects directly the population health. An active volcanic region that regularly emanates toxic gases surrounds our particular context. In addition, the city`s growing industry and vehicle fleet also constitute, other non-natural pollution sources. Climate change irreversibility demands special attention to natural and human factors of contamination, suggesting that air pollution should become a critic element in the everyday life of local community.

In the "Clean Air Act", the United States Environmental Protection Agency (EPA) established the Air Quality Index (AQI), considering a number of pollutant gases such as O3 (ozone), PP (polystyrene particles), CO (carbon monoxide), SO2 (sulfur dioxide) and NO2 (nitrogen dioxide). For each of these pollutants, EPA has established air quality standards to protect public health (MSD, 2017). In Manizales Corpocaldas is the highest environmental authority being responsible for monitoring local air quality. They have placed air quality monitoring stations at different points in the city, focusing on SO2 and NO2 levels (CORPOCALDAS, 2016).

However, as Born and Barry state “...readings from these stations, since they are derived only from specific points, provide a very limited basis for estimating the state of the air mass over extremely large areas" (BARRY \& BORN, 2010). Although, there is significant available information about air pollution, environmental data are hardly taken into account by the community, since “...existing air quality monitoring regimes fail to address the question of how individuals interact with air, by breathing particular mixtures and quantities of pollutants during the course of their everyday activity in the city" (2010).

From this point of view, air quality data became a rich source of information to be interpreted and its sonification an inspiring topic for sound creators, because it calls the attention of common citizens about environmental awareness. When dealing with environmental contamination as a problem to sonification and AD practices, “... air quality should not be considered a property of air, but understood as a relation between air and those who breathe and are affected by it..." (2010). It suggests an ontological transformation of both, the concept of air quality and the relation with local citizens.

\section{Project based research}

Given the nature of the problem, I have adapted methodologies from Design studies, since this field proposes practice-based directions for creative projects (FINDELI, 2008). Design thinking considers both, the aesthetics and functional dimension involving modeling, interactive adjustment and re-design. The projects we will describe in this section, AirQ jacket (ARANGO \& GUTIERREZ, 2016), Esmog Data (ARANGO, GALÁN, QUINTERO 2016) and Breathe!, intend to illustrate the "...distinction between the provision of public information and the practice of a public experiment” (BARRY \& BORN, 2010). By testing different $\mathrm{AD}$ and sonification proposals about the same environmental information, I have observed the implications and potentialities of each communication design. The iteration among the projects produced partial results and conclusions adopted as inputs in the sequence of prototypes.

I find an important difference between sonification, the data-dependent generation of sound and AD, which covers all the topics exploring the auditory channel to convey non-verbal information, including the display environment design (the audio system, speakers, 
listening facilities, etc...) (HUNT \& HERMANN, 2011). While sonification invokes computer music research topics related to the creation of sonic content such as synthesis and DSP methods and representation of data structures, AD leads to other ones related to audio hardware design, diffusion and auralization. In this regard, sonification and AD strategies are discussed separately.

The projects are not intended to be pieces of music, but objects and sound art installations that can be joined as sound-augmented consulting devices. They intend to bridge the gap between the empirical and scientific reading of reality, since they are in constant negotiation in the definition and understanding of our surroundings. Particularly, I am interested in calling the attention about the role that air pollution plays in the everyday life of my local community, by enhancing environmental awareness through a rewarding listening experience.

\subsection{AirQ Jacket (2016)}

AirQ Jacket is a piece of clothing with an attached electronic circuit, which measures contamination levels and temperature and transforms this information to visual and acoustic stimuli. It was created along with fashion designer Maria Paulina Gutierrez whose participation in the laboratory triggered an interchange among electronic, sound and dressmaking crafting, which resulted in an unorthodox item. As a design`s goal, the user should be able to acoustically consult our AD device wherever he/she goes, in order to create healthy courses through the city.

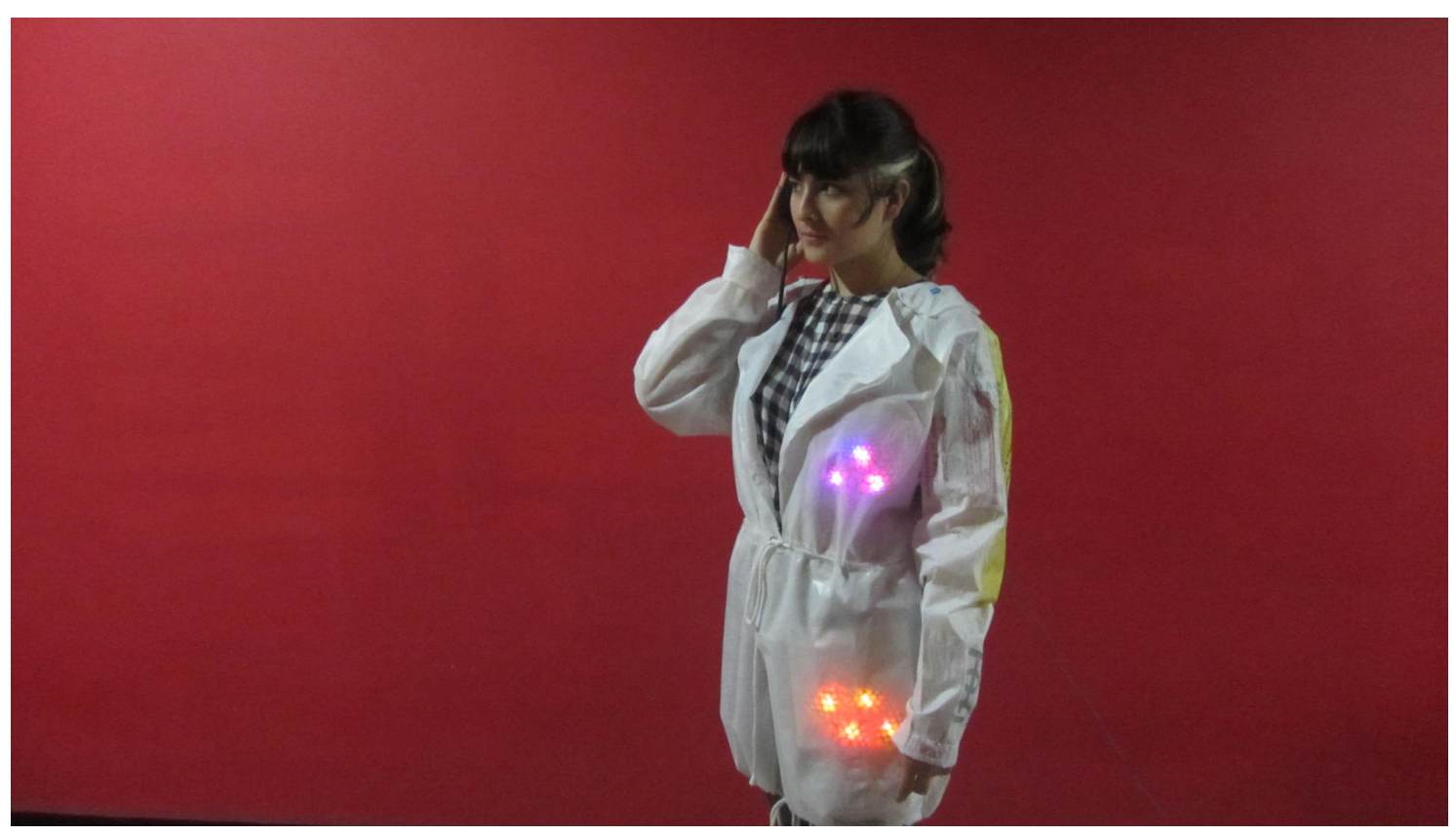

Figure 2: The AirQ jacket sonification system runs in a custom-made, stethoscopic sound artifact.

Since portability and lightness were challenges in the prototype of the AirQ jacket, the circuit was created involving the minimal specifications. We sewed a circuit with two affordable environmental sensors (Mq-135 and DHT-11) providing AirQ and temperature levels, an arduino and some leds. The AD system consisted of a custom-made sthethoscopic artifact attached to the jacket and built with a piezo-electric device located inside a plastic cabinet that totally kills the sound, unless you approach it to the ear.

We faced a challenge when creating sonic content with the arduino microcontrol- 
ler, since it allows a meager repertoire of sound generation possibilities. We opted to work with a couple of sound pulses of energetic attack sounds. The first one displays temperature by varying speed and contamination level by varying pitch. The second pulse acts as a grid of reference, a contextual sound [4] representing "normal" environmental conditions.

\subsection{Esmog Data (2016)}

Esmog Data is an immersive installation presented in the Art Exhibition of the 2016 Balance-Unbalance Festival along with Christian Quintero and Vanessa Gañán. The piece displays through audio and motion graphics the temperature and the concentration of some toxic gases determining air quality index (CO, CO2, SO2 and PM10). The AD device comprises a surround speaker system whose sonic content is constantly changing. The system is feeded by a custom-made environmental station located in the entrance of the exhibition space that regularly refreshes the data.

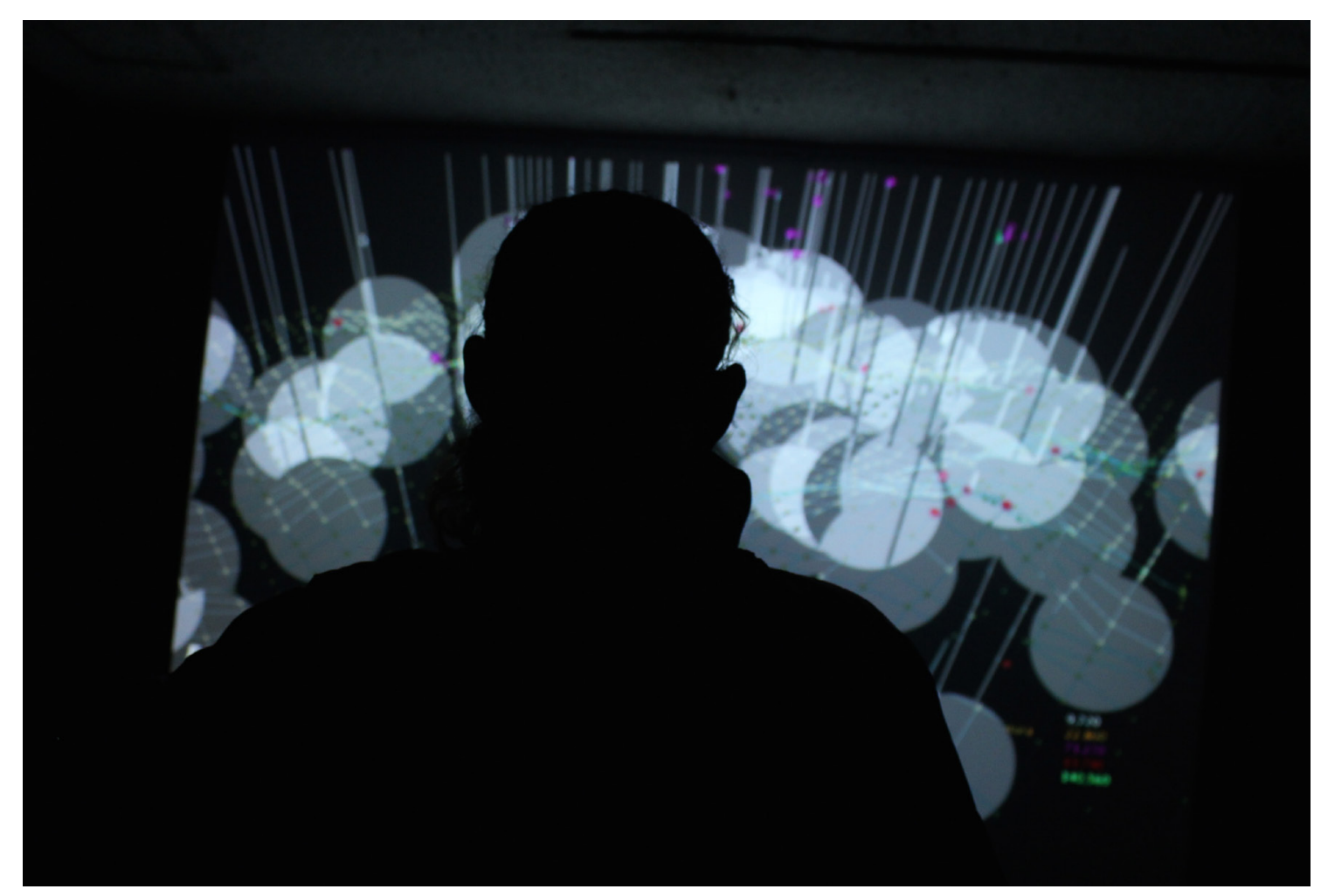

Figure 3: Esmog Data runs in an immersive space.

The sonic content was produced with the Johan Eriksson EcoSYSTEM (ERIKSSON, 2015) pure data patch, since it offered a modular workflow of audio synthesis blocks in which sensor data can be input. Rather than a monitoring system, the sonification design pursued triggering a meaningful listening experience. In this regard, instead of mapping sensor data directly to single synth parameters (pitch, amplitude, rate, adsr), we associated each one of the sensor inputs to many parameters in the synth blocks in the search of more complex musical values. Dennis Smalley vocabulary (SMALLEY, 1997) was helpful to establish the qualities of sound motion attached to each pollutant gas. NO2 was associated to the notion of unidirectional motion (ascent, plane, descent), PM10 to occupation of the spectral space (diffuseness-concentration), CO to textural growth process (agglomeration-dissipation), CO2 to multidirectional motion (exogeny-endogeny). Temperature was associated to the behavioral relationship of dominance-subordination among the toxic gases 


\subsection{Breathe! (2017)}

BREATHE! is a multi-channel installation with no visuals, where the visitor should be able to identify each one of the measured toxic gases as a different sound source in the space. Since we are in the prototyping process we will discuss here some insights and motivations that have been introduced as variables in the practice-based research.

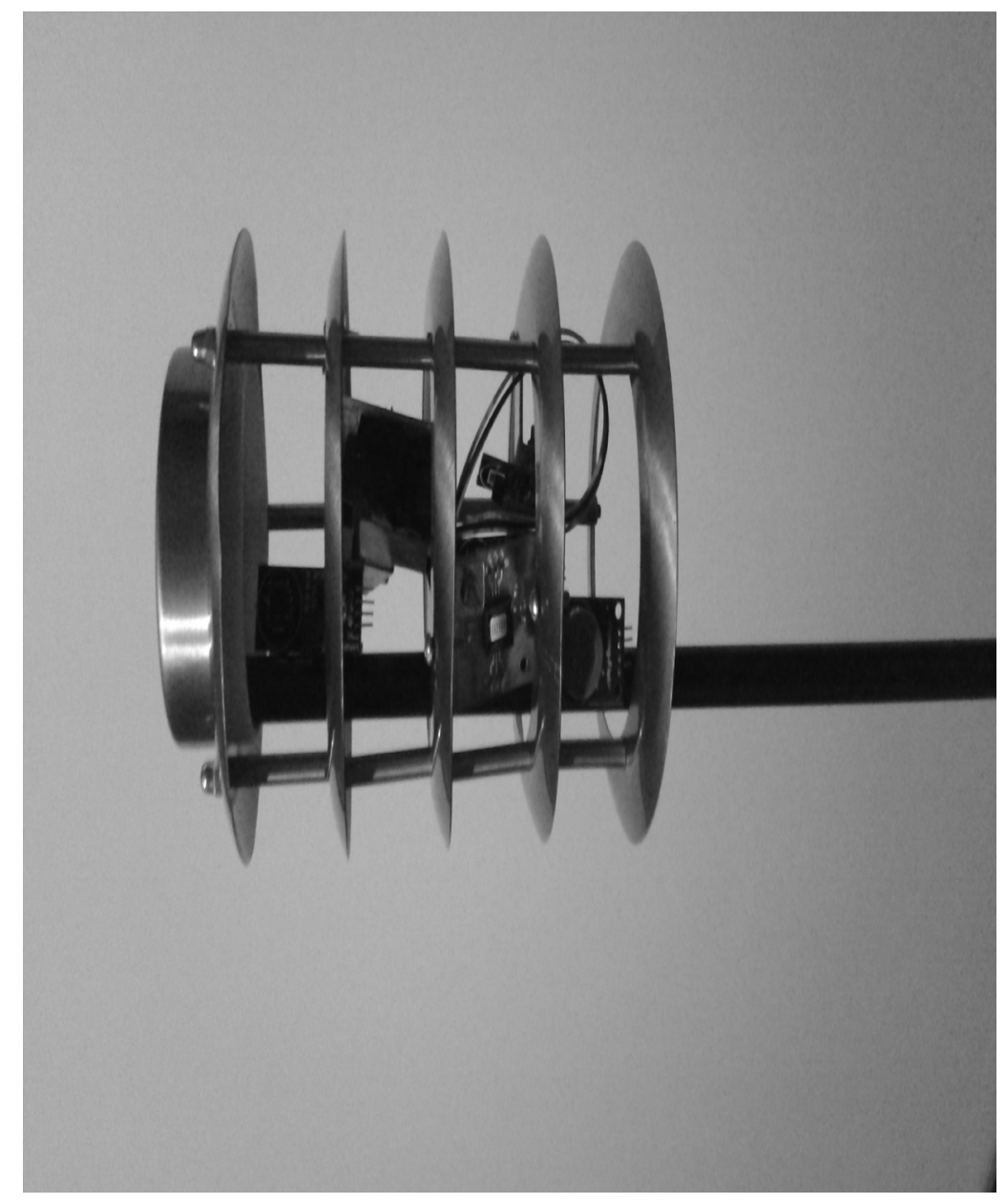

Figure 4: Breathe! air pollution station.

The installation displays six human breathing sound loops, which shrink and stretch from different points in the space according to toxic levels. BREATH! deliberately adopts a denotative sonification strategy, by dealing with human gestures as a attractors to call attention in the meaning making process. The human breathing acts both, as a collateral effect of pollution and as a source of pollution information. This insight was achieved by following vocal scketching rationale: (...) "despite differences in language and tonal range, the apparatus for producing sound is essentially similar for all people. This is beneficial for communication, as it ensures a good framework for understanding the intentions of the communicating partner" (EKMAN \& RINOTT, 2016).

The installation comprises two modules. On the one hand, the AD device, which consists of a multi-speaker space through which the listener can walk in order to approach to each sound source. A more accurate CO2 sensor, a NO2 one and a Wi-Fi module were attached to an improved version of the air monitoring station prototype. Being located outdoors, in the exhibition building terrace, the environmental station update the data regularly. The two modules are connected in real time via network resources. 


\subsection{Discussion}

The three above-described projects propose different solutions for a common challenge: making air quality data more familiar to local citizens, by enriching their listening experience. The interweaved strategies on auditory display and sonification that we will describe seek to face the project`s goal.

\subsubsection{Auditory Display}

AD design is concerned with the situation in which the listener will make the consultation and the context in which he will experience the data. In this regard, the AirQ jacket stethoscopic artifact, that can be consulted while the user is in a city course, is intended to generate a pragmatic informational link between the user and data. As well as other $19^{\text {th }}$-century auditory devices the sthetoscope produces objectification, which is the "... capacity to make external and concrete, and hence situate as perceptually objective” (RICE, 2008). For its part, Esmog Data is intended to produce a sense of immersion by deploying the surround sound and the motion graphics systems in a dark room. As Supper remarks, this sense of immersion rarely depends on a single sense, but rather on the interplay of the senses (SUPPER, 2014). Lastly, Breath! Intends to elicit an interactive relation with sound. The listening space, a room with dimmed light rounded by six speakers where the user can walk and approach to the sound sources, invoke to an exploratory experience through which the subtle differences among breathe audio samples can be figured out.

\begin{tabular}{|l|l|l|l|}
\hline & AirQ JAcket & Esmog Data & Breath \\
\hline AD & Stethoscopic device & Surround 2.1 & 6-channel speaker system \\
Experience & Objective & Inmersive & interactive \\
\hline Sonification & Reference sound & $\begin{array}{l}\text { Abstract musical } \\
\text { Values }\end{array}$ & Vocal sketching \\
Listening & comparing & appraising & proprioception \\
\hline
\end{tabular}

Table 1: Sonification and auditory display strategies summary.

\subsubsection{Sonification}

Sonification design is concerned with the mapping, the creation of the sonic content and the listening strategies needed in deciphering the information encrypted in sound. The AirQ jacket sonification design demands from the user a comparison between two pulses of attack sounds, from which he has to be able to discriminate simple musical values, such as sound pitch and pulse speed. As other technical listening attitudes, it is expected that the user only will feel confortable with the system after a learning period. As it was mentioned, the Esmog Data sonification design seeks to elicit an interest for sound and produce a meaningful listening experience. In this regard, the installation visitor will have to gather the environmental data from complex musical values, such as sound motion and texture qualities, what demands a deep sound appraisal effort. Finally, by sketching sounds with the voice, in Breath! it was possible to observe sound 's emotional and non-verbal communicative aspects. Breathe! sonification design invokes the multimodal aspects of sound meaning by dealing with the tension and relaxation of muscles and activating a sort proprioceptive listening (SMALLEY, 1996). As a result, the sonic content evokes an acoustic reference of the natural pulses of the human body being affected by contamination. 


\section{Acknowledgments}

This work is the result of a research funded by Departamento Administrativo de Ciencia, Tecnología e Innovación (COLCIENCIAS), Grant 2014-656.

\section{References}

ATKINS, D. Sonic Pavilion. Catálogo online de Inhotim, 2009. Retrived from. http://www.inhotim.org.br/inhotim/arte-contemporanea/obras/sonic-pavilion/

ARANGO, J. J. GALÁN, V., QUINTERO, C. Esmog Data, 2016.

https://sonologiacolombia.wordpress.com/lab/esmog-data/

ARANGO, J.J \& GUTIERREZ, M. P. AirQ Jacket, 2016.

https://sonologiacolombia.wordpress.com/lab/airq-jacket/

BARRAS, S. \& VICKERS, J. Sonification Design and Aesthetics. In: (Org) HERMANN, T., HUNT, A., NEUHOFF, H. The sonification Handbook. Logos-Verlag, Berlin, 2011

BERGER, J. \& GROND, F. Parameter Mapping Sonification. In: (Org) HERMANN, T., HUNT, A., NEUHOFF, H. The sonification Handbook. Logos-Verlag, Berlin, 2011.

BORN, G. \& BARRY, A. Art-science: From public understanding to public experiment. Journal of Cultural Economy 3(1), p.103-119, 2010.

[12] CHARLES, D. For the Birds. Paperback. New York, 2000.

CORPOCALDAS. Regional Environmental Plan Management REPM 2007-2019. 2016. Retrieved from http://www.corpocaldas.gov.co/

EKMAN, I., \& RINOTT, M. Using vocal sketching for designing sonic interactions. In. V.A. Proceedings of the 8th ACM conference on designing interactive systems. Brisbane, Australia. p.123131. ACM, 2016.

ERIKSSON, J. EcoSYSTEM. 2015 http://www.monologx.com/ecosystem/

FINDELI. A. Research Through Design and Transdisciplinarity: A Tentative Contribution to the Methodology of Design Research. In: (Org) SWISS DESIGN NETWORK. Focused -- Current Design Research Projects and Methods, Publisher:, Editors: Swiss Design Network, p.67-91, 2008.

HUNT, A. \& HERMANN, T. Interactive Sonification. In: (Org) HERMANN, T., HUNT, A., NEUHOFF, H. The sonification Handbook. Logos-Verlag, Berlin, 2011.

McLAUGHLIN, S. Composers and Chaos: A Survey of Applications of Chaos Theory in Musical Arts and Research. In: V.A. Handbook of Applications of Chaos Theory p. 893-912, 2016

MINISTRY OF SUSTAINABLE DEVELOPMENT. Air Quality Index. Environment and the fight against the climate change. Online, 2017. Retrieved from https://www.airnow.gov/

PALOMBINI, C. Musique Concrète Revisited. Electronic Musicological Review, 4. UFPr Arts Department, 1999

POLLI, A. Atmospherics/weather works: A spatialized meteorological data sonification project. Leonardo 38(1): p. 31-36, 2005

RICE T. Beautiful murmurs: Stethoscopic listening and acoustic objectification. The Senses \& Society .3(3). P. 293-306, 2008 
SMALLEY, D. The listening imagination: Listening in the electroacoustic era. Contemporary Music Review 13 (2), p. 77-107, 1996

SMALLEY, D. Spectromorphology: explaining sound-shapes. Organised Sound, 2(2), p. 107-126, 1997

SOLOMOS, M. Cellular Automata in Xenakis` Music Theory and Practice. In: (Org) SOLOMOS, M., GEORGAKI, A., ZERVOS, G. Definitive Proceedings of the International Symposium Iannis Xenakis. Athens, 2005

SUPPER, A. Sublime frequencies: The construction of sublime listening experiences in the sonification of scientific data. Social Studies of Science. Vol 44(1) p.34-58, 2014

WALKER, B. \& NESS, M. A. Theory of Sonification. In: (Org) HERMANN, T., HUNT, A., NEUHOFF, H. The sonification Handbook. Logos-Verlag, Berlin, 2011.

WORLD HEALTH ORGANIZATION. Gender, Climate Change and Health. The WHO Library Catalogue. Geneva, Switzerland, 2016.

Julián Jaramillo Arango - (PhD) actúa en el campo de la creación musical y audiovisual con medios electrónicos, con un enfoque hacia la música experimental, la comunicación multimodal en Internet y al diseño y desarrollo de aplicaciones e instalaciones interactivas. El trabajo de Jaramillo Arango articula ciencia, arte, tecnología, creatividad, sociedad y comunidad a través de trabajos que exploran diferentes modalidades de interacción con el sonido. Estos trabajos han sido exhibidos en América y Europa en la forma de piezas electroacústicas, performances, intervenciones o instalaciones, entre otros, y también han sido publicados en la forma de textos académicos especializados en el área del sonido. Actualmente Jaramillo Arango reside en Manizales, donde realiza una investigación sobre sonido y espacio urbano como parte de una estancia posdoctoral en el programa de Diseño + Creación de la Universidad de Caldas. 